\title{
Immunological and Clinical Responses following the Use of Antiretroviral Therapy among Elderly HIV-Infected Individuals Attending Care and Treatment Clinic in Northwestern Tanzania: A Retrospective Cohort Study
}

\author{
Bonaventura C. T. Mpondo, ${ }^{1}$ Daniel W. Gunda, ${ }^{2}$ Semvua B. Kilonzo, ${ }^{2}$ and Erick Mgina $^{3}$ \\ ${ }^{1}$ Department of Medicine, College of Health Sciences, The University of Dodoma, Dodoma, Tanzania \\ ${ }^{2}$ Department of Medicine, Catholic University of Health and Allied Sciences, Mwanza, Tanzania \\ ${ }^{3}$ Department of Data Management, National Institute of Medical Research, Tukuyu Unit, Mbeya, Tanzania \\ Correspondence should be addressed to Bonaventura C. T. Mpondo; boniempondo@gmail.com
}

Received 5 October 2015; Revised 9 February 2016; Accepted 14 February 2016

Academic Editor: Vincent C. Marconi

Copyright (C) 2016 Bonaventura C. T. Mpondo et al. This is an open access article distributed under the Creative Commons Attribution License, which permits unrestricted use, distribution, and reproduction in any medium, provided the original work is properly cited.

\begin{abstract}
Background. Limited information exists on adults $\geq 50$ years receiving HIV care in sub-Saharan Africa despite their increasing number. We aimed at studying immunologic and clinical responses to ART in this population. Methods. Data of patients who initiated HAART between 30th of June 2004 and 1st of May 2008 at Sekou Toure Care and Treatment Clinic were retrospectively analyzed. Date of ART initiation was used as a baseline and 48 months as a follow-up date. Immune recovery was defined as a CD4 count of $\geq 350$ cells $/ \mathrm{mm}^{3}$ at 48 months and late presentation as presentation with WHO stage 3 or 4 at clinic enrollment. Proportions of patients reaching this endpoint were compared between the two groups. Results. A total of 728 patients were included in our study; of these $73(10.0 \%)$ were aged 50 years and above. Late presentation was more common in elderly patients than young patients $(65.7 \%$ versus $56.1 \%, P=0.12)$. Proportion of patients with CD4 count $\geq 350$ (immune recovery) was higher in younger patients than in elderly patients, although this was not statistically significant ( $54.5 \%$ versus $44.9 \%, P=0.2)$. Median absolute increase in CD4 at 48 months was higher in younger patients than in elderly patients $\left(+241.5 \mathrm{cells} / \mathrm{mm}^{3}\right.$ versus $+146 \mathrm{cells} / \mathrm{mm}^{3}$, $P=0.007)$. Conclusion. Elderly HIV patients have higher rates of late presentation, with lower immune recovery. Strategies to increase HIV testing in this group are required for early diagnosis and treatment to improve outcomes.
\end{abstract}

\section{Introduction}

Globally the number of people living with HIV at advanced age is increasing [1]. In 2013, UNAIDS estimated that 4.2 million people living with HIV were aged 50 and above. In sub-Saharan Africa which harbors more than seventy percent of all HIV cases, it was estimated that there were 2.4 million people living with HIV at the age 50 and above [1]. The number is almost double that which was observed ten years ago. Projections show that this number will increase further and almost triple by the year 2030 [2]. Prolonged survival among HIV-infected patients following the use of ART explains such an increase [3]. Some studies have shown increased risk of
HIV infection in this population [4]. However routine HIV testing is uncommon in this population, which makes them prone to late testing.

Highly active antiretroviral therapy (HAART) has been shown to be effective in reducing HIV viral load, thereby improving CD4 lymphopenia [5]. However the clinical and immunological responses in elderly patients treated with HAART have been mixed. There is controversy about the rates of CD4 response among elderly patients compared to younger patients. While some studies have shown lower CD4 recovery among older patients [6-8], others have not noted a significant difference in CD4 response between the two groups [9-11]. Many of the existing reports are from 
developed countries. Reports from sub-Saharan Africa which is the most affected region with HIV are scarce. This study aimed at assessing immunological and clinical responses following HAART use among elderly HIV-infected patients.

\section{Materials and Methods}

2.1. Study Design and Study Setting. Retrospective analysis of the data involving ART naïve patients initiating HAART between 30th of June 2004 and 1st of May 2008 at Sekou Toure Regional/Referral Hospital care and treatment clinic (CTC) in Mwanza, Northwestern Tanzania, was done.

HAART was defined as a combination of two nucleoside reverse transcriptase inhibitors plus a nonnucleoside reverse transcriptase inhibitor or a protease inhibitor with or without a pharmacological booster. The age cut-off value was set at 50 years ( $<50$ and $\geq 50$ years old at baseline) as used in other studies $[6,12,13]$.

Collected variables included the age at ART initiation, sex, baseline CD4 cell count, WHO clinical stage at enrollment, occupation, marital status, type of first HAART, indications for ART, and time taken from ART initiation to ART change. Late diagnosis was defined as presentation with WHO clinical stage 3 or 4 at the time of enrollment. Immunological recovery was defined as CD4 cell count $\geq 350$ cells $/ \mathrm{mm}^{3}$ at 48 months of followup. Proportions of patients reaching this endpoint were compared between the two groups.

Data for this study were extracted from patient clinical files and data cleaning and descriptive data analysis was done using Stata software version 12.0 (Statcorp, Texas, USA). Comparisons between the two groups were computed using chi-squared test for categorical variables, nonparametric Wilcoxon rank-sum test for continuous variables, and Student's $t$-test to compare proportions between the groups and the comparison was considered significant at the $P$ value less than 0.05 .

\section{Results}

A total of 728 patients were included in our study; of these $73(10.0 \%)$ were aged 50 years and above. The median age was 37 (IQR 32-42) among younger patients and 54 (IQR 52-57) among the elderly patients. Majority of participants were female in the younger group (69.9\%) and male in the elderly group (58.9\%). Comparisons of the baseline sociodemographic and clinical characteristics of the study participants are summarized in Table 1.

Late diagnosis was more common in elderly patients than young patients $(65.7 \%$ versus $56.1 \%, P=0.12)$. Median absolute increase in CD4 at 48 months was found to be significantly higher in younger patients than in their elderly counterpart $\left(+241.5\right.$ cells $/ \mathrm{mm}^{3}$ versus +146 cells $/ \mathrm{mm}^{3}, P=$ 0.007). We also found the proportion of patients with CD4 count $\geq 350$ cells/ul at the time of followup ( 48 months) to be higher in the younger group (33.9\% versus $30.1 \%, P=0.2)$. The median absolute increase in body weight was found to be similar between the two groups $(5.0 \mathrm{~kg}$ versus $5.0 \mathrm{~kg}, P=$ 0.52 ) as was the proportion of patients who had a change
TABLE 1: Comparison of baseline sociodemographic and clinical characteristics among HIV-infected adults on ART attending care and treatment in Northwestern Tanzania, by age.

\begin{tabular}{|c|c|c|c|}
\hline Variable & $\begin{array}{c}\text { Age }<50 \text { years } \\
\quad(n=654)\end{array}$ & $\begin{array}{l}\text { Age } \geq 50 y \\
(n=73)\end{array}$ & $P$ value \\
\hline Median age years (IQR) & $37(32-42)$ & $54(52-57)$ & \\
\hline $\begin{array}{l}\text { Median baseline CD4 } \\
\text { cells/ul (IQR) }\end{array}$ & $113(43-197)$ & $171.5(72.5-245.5)$ & 0.99 \\
\hline \multicolumn{4}{|l|}{ Sex } \\
\hline Male & $197(30.1 \%)$ & $43(58.9 \%)$ & \\
\hline Female & $457(69.9 \%)$ & $30(41.1 \%)$ & $<0.0001$ \\
\hline Occupation & & & 0.99 \\
\hline Unemployed & $26(4.0 \%)$ & $3(4.1 \%)$ & \\
\hline Employed & $58(8.9 \%)$ & $2(2.7 \%)$ & \\
\hline Peasant & $383(58.6 \%)$ & $45(61.6 \%)$ & \\
\hline Petty trader & $182(27.8 \%)$ & $20(27.4 \%)$ & \\
\hline \multicolumn{4}{|l|}{ Marital status } \\
\hline Single & $105(16.1 \%)$ & $4(5.5 \%)$ & \\
\hline Married & $346(52.9 \%)$ & $41(56.2 \%)$ & \\
\hline Divorced & $90(13.8 \%)$ & $6(8.2 \%)$ & \\
\hline Widowed & $104(15.9 \%)$ & $22(30.1 \%)$ & 0.004 \\
\hline Cohabiting & $9(1.4 \%)$ & 0 & \\
\hline \multicolumn{4}{|l|}{$\begin{array}{l}\text { WHO clinical stage at } \\
\text { enrollment }\end{array}$} \\
\hline Stages 1 and 2 & $287(43.9 \%)$ & $26(34.3 \%)$ & \\
\hline Stages 3 and 4 & $367(56.1 \%)$ & $48(65.7 \%)$ & 0.115 \\
\hline \multicolumn{4}{|l|}{ Indication for ART } \\
\hline Adult CD $4<200$ & $525(80.4 \%)$ & $54(74.0 \%)$ & \\
\hline Adult WHO stage 3 & $88(13.5 \%)$ & $15(20.6 \%)$ & \\
\hline with $\mathrm{CD} 4<350$ & $12(1.8 \%)$ & 0 & \\
\hline Adult WHO stage 4 & $17(2.6 \%)$ & $1(1.4 \%)$ & \\
\hline Pregnancy & $11(1.7 \%)$ & $3(4.1 \%)$ & 0.17 \\
\hline $\begin{array}{l}\text { Body weight at } \\
\text { enrollment (IQR) }\end{array}$ & $54(48-60)$ & $55(50-60)$ & 0.87 \\
\hline
\end{tabular}

in ART regimen within the 48 months of followup $(49.6 \%$ versus $38.4 \%, P=0.06$ ). The proportion of patients who had opportunistic infection at 48 months was similar between the groups $(4.6 \%$ versus $4.1 \%, P=0.81)$. Comparisons of immunological and clinical responses are summarized in Table 2.

\section{Discussion}

This study aimed at assessing the immunological response following the use of ART in HIV-infected patients aged 50 and above. Out of 728 study participants, $73(10 \%)$ were aged 50 years and above. The age cut-off was set at 50 years as suggested in literature [12]. Elderly patients were diagnosed late compared to younger patients, although not significantly so. After 48 months of followup, the absolute median increase in CD4 count was significantly lower in elderly patients than in younger patients. More patients in the younger group had attained CD 4 of $\geq 350$ cells/ul months of followup. 
TABLE 2: Clinical and immunological outcomes following the use of ART among HIV-infected adults attending care and treatment centre in Northwestern Tanzania, by age and sex.

\begin{tabular}{|c|c|c|c|c|}
\hline \multirow{3}{*}{ Variable } & \multicolumn{4}{|c|}{ Sex } \\
\hline & \multicolumn{2}{|c|}{ Male $n(\%)$} & \multicolumn{2}{|c|}{ Female $n(\%)$} \\
\hline & $15-49$ & $\geq 50$ & $15-49$ & $\geq 50$ \\
\hline \multicolumn{5}{|c|}{ CD4 counts of cell/ul } \\
\hline$\leq 350$ & $68(34.3)$ & $15(34.9)$ & $117(25.6)$ & $12(40.0)$ \\
\hline$>350$ & $53(26.8)$ & $12(27.9)$ & $169(37.0)$ & $10(33.3)$ \\
\hline \multirow[t]{2}{*}{ Missing } & $77(38.9)$ & $16(37.2)$ & $171(37.2)$ & $8(26.7)$ \\
\hline & 0.98 & & 0.2 & \\
\hline \multicolumn{5}{|c|}{ Change in ART } \\
\hline Yes & $87(43.9)$ & $29(67.4)$ & $238(52.1)$ & $16(53.3)$ \\
\hline No & $109(55.1)$ & $14(52.6)$ & $216(47.3)$ & $14(46.7)$ \\
\hline \multirow[t]{2}{*}{ Missing } & $2(1.0)$ & $0(0.0)$ & $3(0.7)$ & $0(0.0)$ \\
\hline & 0.02 & & 0.9 & \\
\hline \multicolumn{5}{|c|}{$\begin{array}{l}\text { Opportunistic infection } \\
\text { at follow-up }\end{array}$} \\
\hline Yes & $15(7.6)$ & $7(16.3)$ & $23(5.0)$ & $2(6.7)$ \\
\hline No & $183(92.4)$ & $36(83.7)$ & $434(95.0)$ & $28(93.3)$ \\
\hline \multirow[t]{2}{*}{ Missing } & $0(0.0)$ & $0(0.0)$ & $0(0.0)$ & $0(0.0)$ \\
\hline & 0.07 & & 0.69 & \\
\hline \multicolumn{5}{|c|}{$\begin{array}{l}\text { Reported admission at } \\
\text { follow-up }\end{array}$} \\
\hline Yes & $27(13.6)$ & $6(14.0)$ & $72(15.8)$ & $1(3.3)$ \\
\hline No & $171(86.4)$ & $37(86.0)$ & $385(84.2)$ & $29(96.7)$ \\
\hline \multirow[t]{2}{*}{ Missing } & $0(0.0)$ & $0(0.0)$ & $0(0.0)$ & $0(0.0)$ \\
\hline & 0.96 & & 0.06 & \\
\hline \multicolumn{5}{|c|}{$\begin{array}{l}\text { Other comedications at } \\
\text { follow-up }\end{array}$} \\
\hline Yes & $179(90.4)$ & $41(95.4)$ & $421(92.1)$ & $30(100.0)$ \\
\hline No & $16(8.1)$ & $2(4.6)$ & $33(7.2)$ & $0(0.0)$ \\
\hline \multirow[t]{2}{*}{ Missing } & $3(1.5)$ & $0(0.0)$ & $3(0.7)$ & $0(0.0)$ \\
\hline & 0.52 & & 0.28 & \\
\hline
\end{tabular}

Proportions at 48 months of patients who changed ART regimen during followup were more in elderly patients than in younger patients, although not significantly so. However, the median weight gain was comparable between the two groups.

Studies comparing the efficacy of ART in elderly HIVinfected patients have been done elsewhere [10, 13-15]. Similar to our findings, other studies also found immunological response to be decreasing with increasing age $[8,16]$. This can be explained by decreasing thymic volume with increasing age [17]. There is also a decline in production of naïve $\mathrm{T}$ cells with increasing age [18]. Old age is also associated with reduced memory $\mathrm{T}$ cell populations, impaired $\mathrm{T}$ cell functionality, and reduced number of properly functioning CD8 cytotoxic T cells [19].

The late testing in elderly patients has been described in other studies $[15,20,21]$. In our study, we also found that more elderly patients presented with HIV WHO clinical stages 3 and 4 diagnosed with advanced HIV (WHO clinical stage 3 or 4) compared to younger patients. However, the difference was not statistically significant. This is due to the fact that late presentation is also common in other age groups in subSaharan Africa as shown in other studies. Late diagnosis has been associated with impaired immune response [9], clinical progression, and increased risk of mortality [22]. More than half of the elderly patients (65.7\%) in our study presented with advanced HIV. Other studies also found late presenters among elderly HIV-infected patients to be above $50 \%[12,21,22]$. One of the reasons for late diagnosis could be the overlap between symptoms of HIV and those associated with ageing. Clinicians are also high unlikely to suspect HIV in this population, something that may delay the diagnosis.

Our study had several limitations. Analysis was based on data retrieved retrospectively from clinic database and patients' files; a lot of data was missing. Some important parameters such as treatment adherence are not routinely documented during clinic visit and could not be analyzed despite its importance. This study was based on a single clinic; the results may not necessarily be generalizable. In our study, there were few elderly patients in the study participants compared to younger ones. Our study included patients initiated on ART in June 2004 to May 2008. This long period could have contributed to the high rates of missing values. The missing data were equally distributed between groups and would not therefore be the reason for bias. To the best of our knowledge, this is the first study from Tanzania reporting on immunological responses following the use of ART among elderly HIV patients.

\section{Conclusion}

Elderly HIV-infected patients have an immunological response to ART. However their response is significantly lower than that observed in younger patients. The low immune response could be contributed by the late diagnosis of the disease which is more observed in elderly patients than younger patients in addition to the immunosenescence phenomena. We believe that our findings when coupled with the available guidelines for management of HIV patients have the potential to increase the rate of HIV testing with a subsequent early diagnosis and management. In addition, further studies are necessary to establish the long term outcome of these patients as well as the possibility of drug resistance.

\section{Conflict of Interests}

The authors declare that they have no conflict of interests.

\section{Acknowledgment}

The authors would like to acknowledge the assistance provided by members of staff of HIV Care and Treatment Clinic, Sekou Toure Regional/Referral Hospital. 


\section{References}

[1] M. Mahy, C. S. Autenrieth, K. Stanecki, and S. Wynd, "Increasing trends in HIV prevalence among people aged 50 years and older: evidence from estimates and survey data," AIDS, vol. 28, supplement 4, pp. S453-S459, 2014.

[2] J. Negin and R. G. Cumming, "HIV infection in older adults in sub-Saharan Africa: extrapolating prevalence from existing data," Bulletin of the World Health Organization, vol. 88, no. 11, pp. 847-853, 2010.

[3] S. C. Ball, "Increased longevity in HIV: caring for older HIVinfected adults," Care Management Journals: Journal of Case Management; The Journal of Long Term Home Health Care, vol. 15, no. 2, pp. 76-82, 2014.

[4] A. Sankar, A. Nevedal, S. Neufeld, R. Berry, and M. Luborsky, "What do we know about older adults and HIV? a review of social and behavioral literature," AIDS Care, vol. 23, no. 10, pp. 1187-1207, 2011.

[5] C. Arici, D. Ripamonti, V. Ravasio et al., "Long-term clinical benefit after highly active antiretroviral therapy in advanced HIV-1 infection, even in patients without immune reconstitution," International Journal of STD \& AIDS, vol. 12, no. 9, pp. 573-581, 2001.

[6] S. Grabar, I. Kousignian, A. Sobel et al., "Immunologic and clinical responses to highly active antiretroviral therapy over 50 years of age. Results from the French Hospital Database on HIV," AIDS, vol. 18, no. 15, pp. 2029-2038, 2004.

[7] G. R. Kaufmann, H. Furrer, B. Ledergerber et al., "Characteristics, determinants, and clinical relevance of CD4 T cell recovery to $<500 \mathrm{Cells} / \mu \mathrm{L}$ in HIV type 1 -infected individuals receiving potent antiretroviral therapy," Clinical Infectious Diseases, vol. 41, no. 3, pp. 361-372, 2005.

[8] J.-P. Viard, A. Mocroft, A. Chiesi et al., "Influence of age on CD4 cell recovery in human immunodeficiency virus-infected patients receiving highly active antiretroviral therapy: evidence from the EuroSIDA study," The Journal of Infectious Diseases, vol. 183, no. 8, pp. 1290-1294, 2001.

[9] L. Cuzin, C. Delpierre, S. Gerard, P. Massip, and B. Marchou, "Immunologic and clinical responses to highly active antiretroviral therapy in patients with HIV infection aged $>50$ years," Clinical Infectious Diseases, vol. 45, no. 5, pp. 654-657, 2007.

[10] M. Tumbarello, R. Rabagliati, K. De Gaetano Donati et al., "Older HIV-positive patients in the era of highly active antiretroviral therapy: changing of a scenario," AIDS, vol. 17, no. 1, pp. 128-131, 2003.

[11] M. Tumbarello, R. Rabagliati, K. de Gaetano Donati et al., "Older age does not influence CD4 cell recovery in HIV-1 infected patients receiving highly active antiretroviral therapy," BMC Infectious Diseases, vol. 4, article 46, 2004.

[12] J. R. Blanco, I. Jarrín, M. Vallejo et al., "Definition of advanced age in HIV infection: looking for an age cut-off," AIDS Research and Human Retroviruses, vol. 28, no. 9, pp. 1000-1006, 2012.

[13] R. M. Grimes, M. E. Otiniano, M. C. Rodriguez-Barradas, and D. Lai, "Clinical experience with human immunodeficiency virus-infected older patients in the era of effective antiretroviral therapy," Clinical Infectious Diseases, vol. 34, no. 11, pp. 15301533, 2002.

[14] H. Knobel, A. Guelar, G. Valldecillo et al., "Response to highly active antiretroviral therapy in HIV-infected patients aged 60 years or older after 24 months follow-up," AIDS, vol. 15, no. 12, pp. 1591-1593, 2001.
[15] G. Orlando, P. Meraviglia, L. Cordier et al., "Antiretroviral treatment and age-related comorbidities in a cohort of older HIV-infected patients," HIV Medicine, vol. 7, no. 8, pp. 549-557, 2006.

[16] R. Manfredi and F. Chiodo, "A case-control study of virological and immunological effects of highly active antiretroviral therapy in HIV-infected patients with advanced age," AIDS, vol. 14, no. 10, pp. 1475-1477, 2000.

[17] R. C. Kalayjian, A. Landay, R. B. Pollard et al., "Age-related immune dysfunction in health and in human immunodeficiency virus (HIV) disease: association of age and HIV infection with naive $\mathrm{CD}^{+}$cell depletion, reduced expression of $\mathrm{CD} 28$ on $\mathrm{CD}^{+}$cells, and reduced thymic volumes," The Journal of Infectious Diseases, vol. 187, no. 12, pp. 1924-1933, 2003.

[18] K. Naylor, G. Li, A. N. Vallejo et al., "The influence of age on T cell generation and TCR diversity," The Journal of Immunology, vol. 174, no. 11, pp. 7446-7452, 2005.

[19] R. B. Effros, "T cell replicative senescence: pleiotropic effects on human aging," Annals of the New York Academy of Sciences, vol. 1019, pp. 123-126, 2004.

[20] S. Grabar, L. Weiss, and D. Costagliola, "HIV infection in older patients in the HAART era," The Journal of Antimicrobial Chemotherapy, vol. 57, no. 1, pp. 4-7, 2006.

[21] S. Mensforth, L. Goodall, N. Bodasing, and J. Coultas, "Late diagnosis among our ageing HIV population: a cohort study," Journal of the International AIDS Society, vol. 17, supplement 3, no. 4, Article ID 19692, 2014.

[22] R. D. Smith, V. C. Delpech, A. E. Brown, and B. D. Rice, "HIV transmission and high rates of late diagnoses among adults aged 50 years and over," AIDS, vol. 24, no. 13, pp. 2109-2115, 2010. 


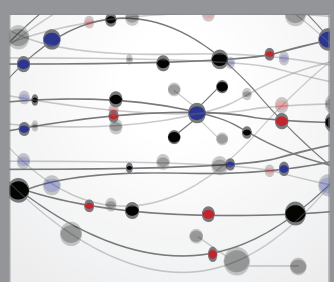

The Scientific World Journal
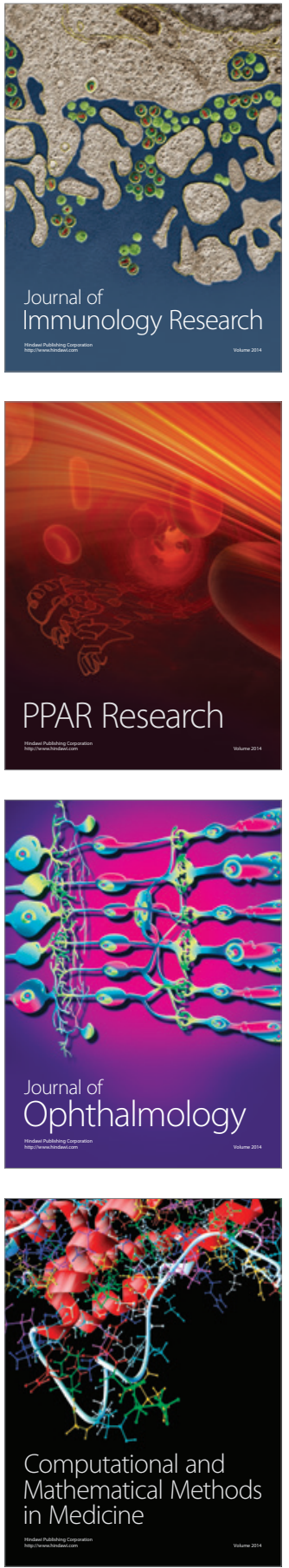

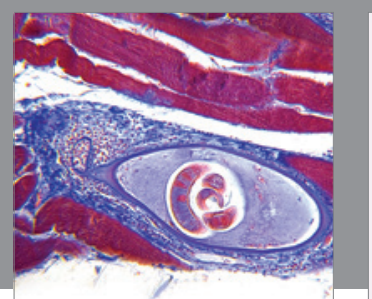

Gastroenterology Research and Practice

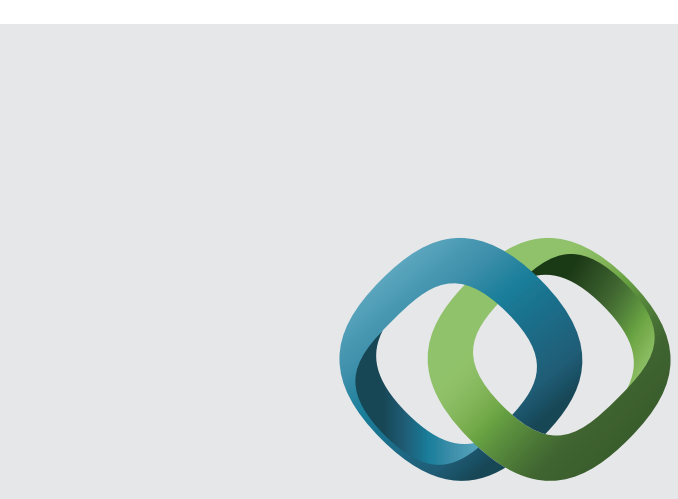

\section{Hindawi}

Submit your manuscripts at

http://www.hindawi.com
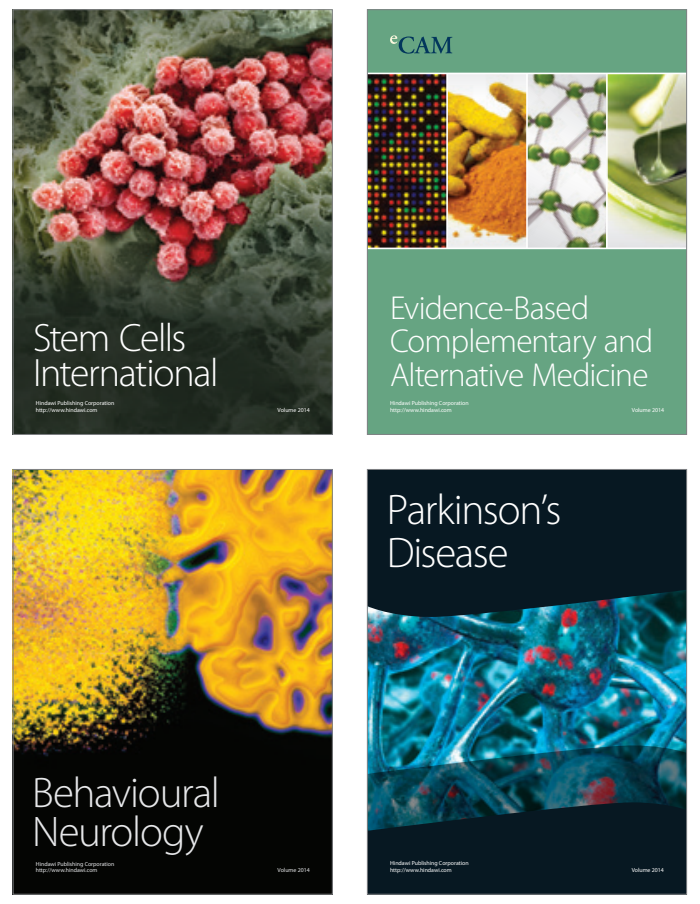
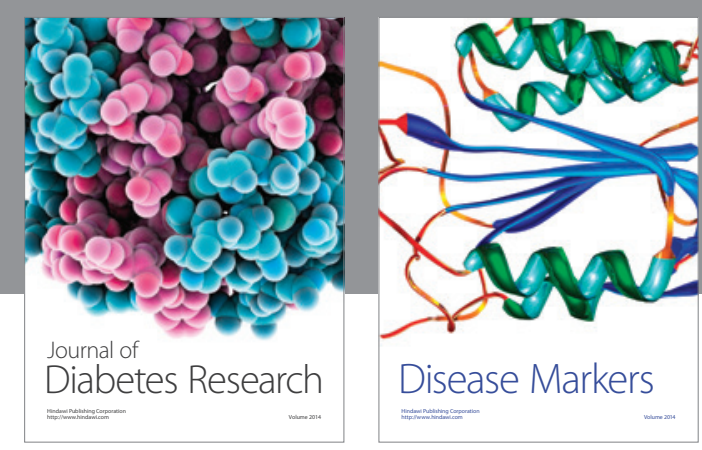

Disease Markers
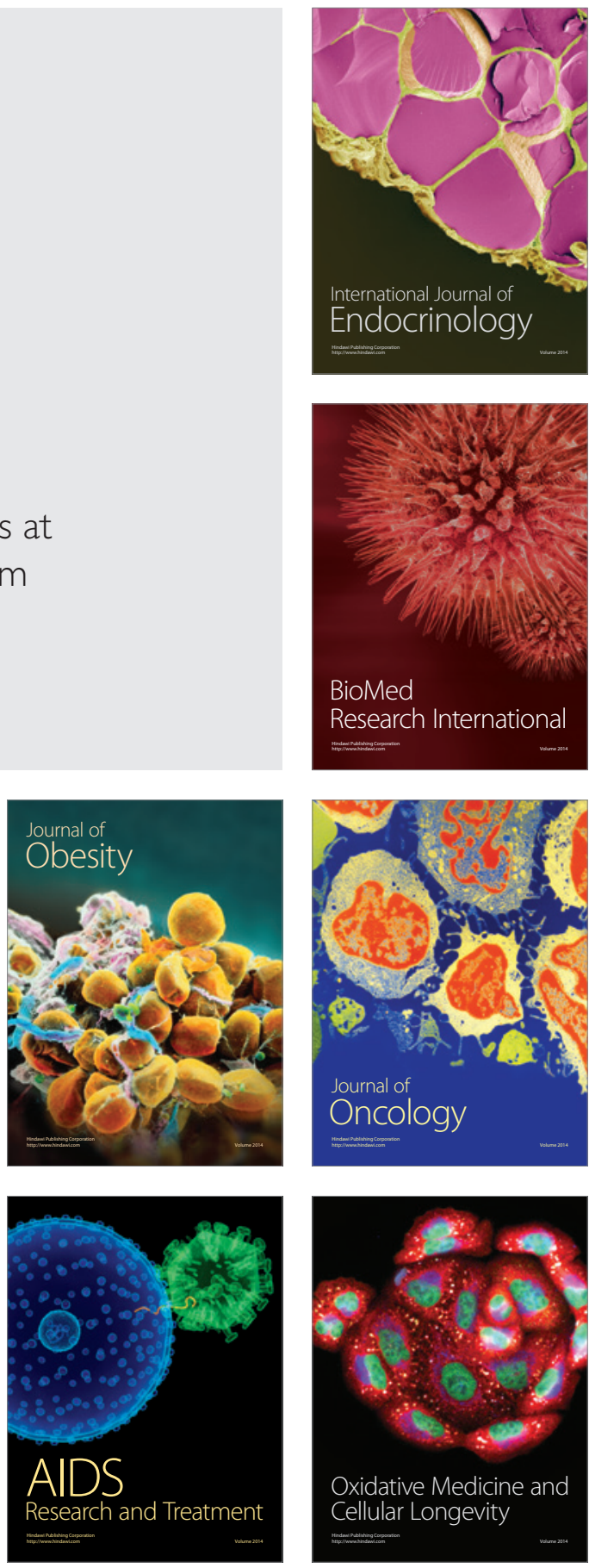